\title{
What Else Matters? Competency of Malaysian Educators in Technical and Vocational Education: A Scoping Review
}

\author{
Nurul Ain Saipudin $^{1^{*}}$, Nornazira Suhairom ${ }^{1}$ \\ ${ }^{1}$ Department of Technical and Vocational Education, School of Education, Faculty of Social Sciences and Humanities, \\ Universiti Teknologi Malaysia (UTM), Skudai, Johor Bahru, 81310 MALAYSIA \\ *Corresponding Author
}

DOI: https://doi.org/10.30880/ojtp.2021.06.01.004

Received 16 December 2020; Accepted 15 March 2021; Available online 31 March 2021

\begin{abstract}
This article reported up-to-date studies on competencies issues of TVET educators from Malaysia's institutions. Various electronic databases were used and through systematic selection, 12 scientific articles were identified. The findings of the identified studies were organized by five emerging key matters (1) imbalance of technical and non-technical competency; (2) lack of practical skills training and work experience; (3) issue of greening TVET; (4) lack of self-concept and self-confidence in improving performance; and (5) lack of pedagogical approach for social and humanity competency. This review indicates that these five key matters about competency apply to the current norm of Malaysian TVET educators across all ages. Thus, the review concludes by suggesting educators to progressively increase their knowledge and skills through theoretical and practical training and real experiences acquired from home and abroad. This will enhance their competencies in line with the national and international core standards, that aim to produce skilled, knowledgeable, and high-quality workforces in various TVET industries.
\end{abstract}

Keywords: Competency, Technical and Vocational Education and Training, TVET educator

\section{Introduction}

Technical Vocational Education and Training (TVET) has been reputable for decades. This can be seen with progressive government efforts through the $10^{\text {th }}$ until $12^{\text {th }}$ Malaysian Plan to mainstreaming and broadening TVET education, for the enhancement of the skillful, and higher employability of the future workforces (Arifin \& Rasdi, 2017). According to the 2014 EFA Global Monitoring Report, there was a high demand for more effort by the government regarding qualified, competent, and motivated educators in the TVET field (UNESCO Global Monitoring Report, 2014). Vast studies have agreed on the fact of competent and knowledgeable educators as the thrust force in processes of teaching and learning, especially in the enactment of each educational institution's decree (Kleickmann et al. 2012; Wesselink et al. 2010). Thus, it is a challenge and high needs of having TVET educators with the right set of new, advanced skills, knowledge, and attitudes that align with globalization shifting and real-time challenges happened in the workplace, industry, and TVET institution (Ismail et al., 2017; Hamisu et al., 2017).

"Testing for Competence Rather than Intelligence". This is the first article by Professor David McClelland in 1973, that introduced the concept of competency. These include knowledge, skills, traits, self-concepts, and motives. Many other scholars like Boyatriz (1982) and Spencer and Spencer (1993), have related the concept of competence with performance improvement. As time goes by, it became a norm for competency studies to combine attitude, knowledge, and skills with worker's qualifications, for better job performance (ILO 2010). Competency is perceived as an important indicator for an individual and organization's level of capacity and capability, in performing quality jobs as well as the ability to be competitive in the market (Ismail et al., 2017).

Guthrie (2010) mentioned the importance of a TVET educator who has been well-trained in the knowledge field, as well as during transfer and assessment of teaching. TVET educator should be able to demonstrate their skills, and 
endlessly develops, and improve their capability in acquiring broader knowledge and skills in the field. In worldwide view, several studies on TVET educator have related multiple competencies to enhance their quality jobs performance, such as pedagogical and professional competency (Mirzagitova \& Akhmetov 2015); social management, teaching, technical and technological skills (Othman et al. 2011); leadership and personality competency and student management (Aliakbari \& Darabi 2013) as well as self-reflection competency and communication competency (Diep \& Hartmann 2016). Many local scholars, Ismail et al., (2019), Hamisu et al. (2017), and Ismail et al. (2017) have expressed, the insufficiency study on the competency model, job profiles, and issues on TVET educators' competencies in Malaysia. Since not much has been done, it is a challenge that should be accepted. Thus, this study aims to review and further explore current key issues on competencies of TVET educators in Malaysia.

\section{Methodology}

Figure 1 shows the review flow chart as adapted from PRISMA 2009 (Moher et al., 2009). An online database was used to search pertinent published articles. Among the web-based service providers were Science Direct, Scopus, Web of Science, and Wiley Online Library ( $\mathrm{n}=122$ articles). Additional information on relevant studies was searched using Google Scholar ( $\mathrm{n}=25$ articles). All the articles were scanned to retrieve the related studies on "Malaysia", "TVET", "educator", and "competency". Since there has been limited research when used the term of TVET, a term "technical" and "vocational" are used instead. Research focusing on those competencies was rather assorted, specific keywords terms were used such as "constructs", "skills", "attributes", "traits", and "characteristics". During the identification stage, there was no limitation on searching relevant studies, all concept papers, research papers, conference proceedings, and books were recognized. Therefore, after 92 duplicated articles were removed and 55 articles screened for relevance, there were only 20 left considered relevant and eligible (Figure 1). Of these, 35 were then excluded for several reasons, such as the authors did not mention or elaborate thoroughly the population and study design used in their studies, articles were not in the English language, as well as full-article was failed to retrieve (Figure 1). In total, only 12 relevant studies had fulfilled these review criteria and were included in the qualitative analysis. The criteria include (1) only articles written in English; (2) the selected published research and concept papers from 2010 to 2020; and (3) and lastly the accessible full-text studies regarding the competencies of TVET educators in Malaysia's education and training institutions.
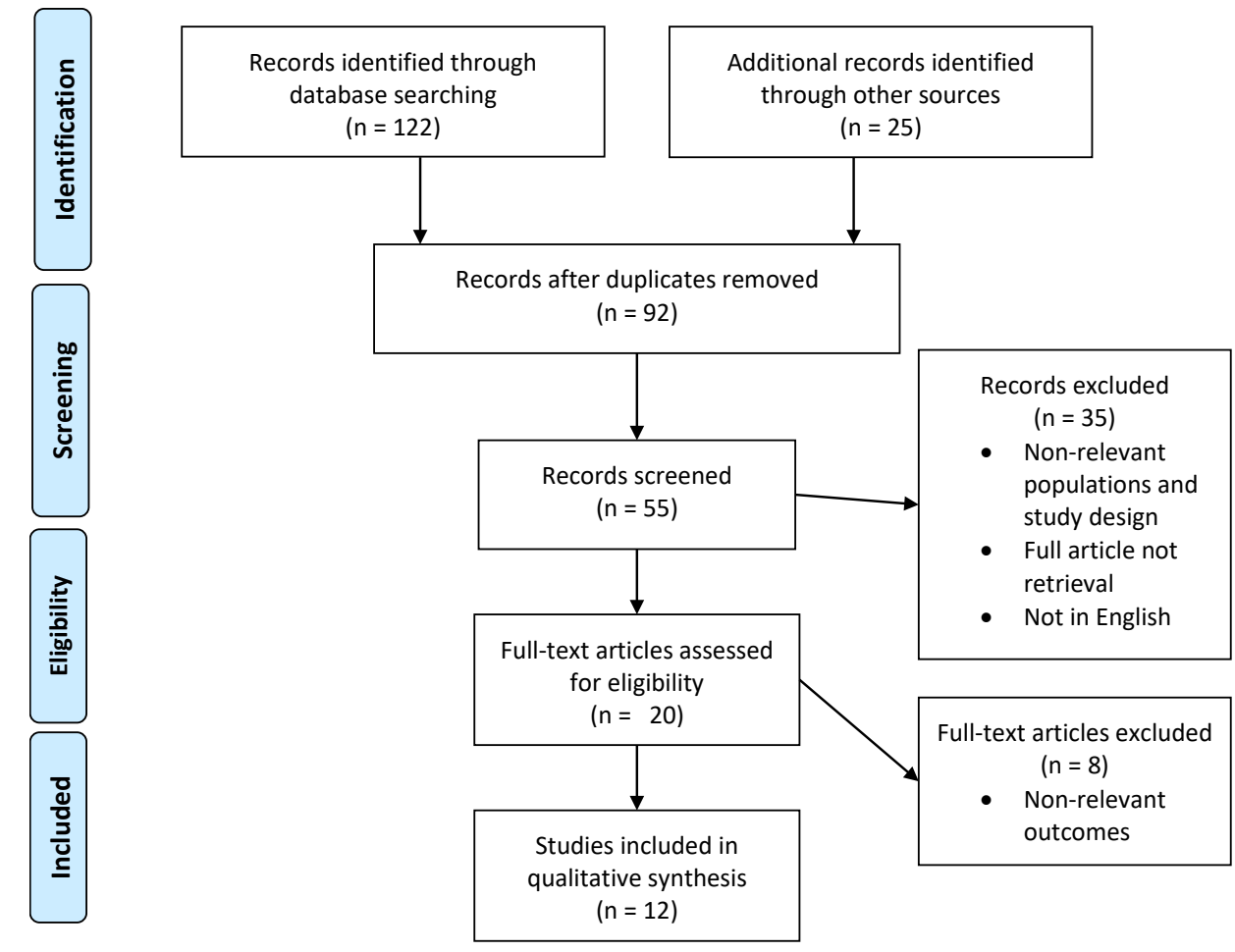

Fig. 1 - Review flow chart (adapted from PRISMA 2009) 


\section{Results and Discussions}

According to Table 1, twelve articles had been chosen and reviewed. Throughout the reviews, the current key matters on competencies of Malaysian TVET educators that have been recognized are (1) imbalance of technical and nontechnical competency; (2) lack of practical skills training and work experience; (3) issue of greening TVET; (4) lack of self-concept and self-confidence in improving performance; and (5) lack of pedagogical approach for social and humanity competency.

Table 1 - Summary of competency studies on TVET educators

\begin{tabular}{|c|c|c|c|c|}
\hline No & Authors & Sample & $\begin{array}{l}\text { Proposed Competency Model } \\
\text { (Constructs) }\end{array}$ & Suggestion/Limitation \\
\hline 1. & $\begin{array}{l}\text { Arifin \& } \\
\text { Rasdi, } \\
(2017)\end{array}$ & $\begin{array}{l}\text { Vocational } \\
\text { college } \\
\text { Teachers }\end{array}$ & $\begin{array}{l}\text { 1. Teaching Competency } \\
\text { 2. Professional Competency } \\
\text { 3. Communication Competency } \\
\text { 4. Personal Competency }\end{array}$ & $\begin{array}{l}\text { Greening TVET with green skills } \\
\text { and economic development }\end{array}$ \\
\hline 2. & $\begin{array}{l}\text { Hamid et } \\
\text { al. } \\
(2019)\end{array}$ & $\begin{array}{l}\text { Senior } \\
\text { academics } \\
\text { from the } \\
\text { school of } \\
\text { Education }\end{array}$ & $\begin{array}{l}\text { Generic green skills } \rightarrow \text { technical skills, } \\
\text { knowledge, values, and attitudes } \\
\text { required by the workforce to develop } \\
\text { and support social, economic, and } \\
\text { environmental sustainability }\end{array}$ & $\begin{array}{l}\text { Generic green skills in teaching and } \\
\text { learning would help in future } \\
\text { employability. }\end{array}$ \\
\hline 3. & $\begin{array}{l}\text { Arifin et } \\
\text { al. } \\
(2018)\end{array}$ & $\begin{array}{l}\text { Vocational } \\
\text { College } \\
\text { Teachers }\end{array}$ & $\begin{array}{l}\text { 1. Teaching Competency } \\
\text { 2. Professional Competency } \\
\text { 3. Communication Competency } \\
\text { 4. Personal Competency }\end{array}$ & $\begin{array}{l}\text { An empirical study should be } \\
\text { carried out with different } \\
\text { perspectives in diverse vocational } \\
\text { institutions to retest a similar } \\
\text { framework for EJP. }\end{array}$ \\
\hline 4. & $\begin{array}{l}\text { Arifin et } \\
\text { al. } \\
(2017)\end{array}$ & $\begin{array}{l}\text { Vocational } \\
\text { college } \\
\text { Teachers }\end{array}$ & $\begin{array}{l}\text { 1. Cognitive Competencies } \\
\text { 2.Functional Competencies } \\
\text { 3.Attitudes and Behaviors } \\
\text { 4.Motives and Traits }\end{array}$ & $\begin{array}{l}\text { Additional studies could be } \\
\text { proposed across different } \\
\text { industry and segments to retest the } \\
\text { proposed framework. }\end{array}$ \\
\hline
\end{tabular}

5. Hamisu TVET 1.Individual competencies

et al. instructor in 2.Organizational competencies

(2017) ILP 3. Thinking competencies

4. Application competencies

*based on MHRDP

6. Abdullah Vocational 1. Professional ethics

et al. teachers 2. Professional character

(2019) 3. Potential

4. Practice of professional learning community

7. Abdul TVET 1.Technical aspect

Suki et instructor in 2.Learning and methodology aspect

al. ILP 3. Humanity and social aspect

(2018)

8. Ismail et TVET

al. lecturers

1.Technical competency

(2019)

2.Pedagogy competency

3.Personal competency

9. Ismail et TVET 1.Personal Traits and Professionalism;
al. teachers/trai
(2018) ners
2.Teaching and Learning and Training
3.Skill, Technical, and Innovation

TVET teachers perceived all the twenty-five competencies as important and the findings also show the accepted Cronbach's Alpha.

Positive relationships between the dimensions of professionalism and generic skills.

There is a difference in the level of mastery of the learning and methodology aspect between middle-level instructors and experienced instructors.

The development of competency items for vocational teachers at MPSTI under the MOHR and MOYS based on the NOSS module is crucial.

Lack of promotion for educators and proper guidelines for promoting educators. 


\begin{tabular}{|c|c|c|c|c|}
\hline 10. & $\begin{array}{l}\text { Ismail et } \\
\text { al., } \\
(2017)\end{array}$ & $\begin{array}{l}\text { TVET } \\
\text { teachers/trai } \\
\text { ners }\end{array}$ & $\begin{array}{l}\text { 1. Professional skill and knowledge } \\
\text { 2. Professional teaching and learning } \\
\text { process } \\
\text { 3. Personal and professional } \\
\text { attributes } \\
\text { 4. Professional industries } \\
\text { and communities. }\end{array}$ & $\begin{array}{l}\text { The government, TVET } \\
\text { institutions, and stakeholders } \\
\text { should give greater credit to the } \\
\text { national core standard for TVET } \\
\text { teachers as the main criterion for } \\
\text { selecting qualified and capable } \\
\text { TVET teachers. }\end{array}$ \\
\hline 11. & $\begin{array}{l}\text { Ismail et } \\
\text { al. } \\
(2016)\end{array}$ & $\begin{array}{l}\text { TVET } \\
\text { teachers }\end{array}$ & $\begin{array}{l}\text { 1.Basic and common } \\
\text { 2.Core/functional } \\
\text { 3.Pedagogical } \\
\text { 4. Social } \\
\text { 5.Personality } \\
\text { 6.Professional } \\
\text { 7.Educational laws and regulations } \\
\text { 8.Pedagogy and pedagogical } \\
\text { 9.psychology } \\
\text { 10.Didactic and teaching methodology } \\
\text { 11. Subject-based methodology }\end{array}$ & $\begin{array}{l}\text { Vocational teachers should adhere } \\
\text { to TVET standards including } \\
\text { pedagogical approaches for social } \\
\text { competency. It is suggested that a } \\
\text { teacher must possess teaching and } \\
\text { learning skills, professional } \\
\text { attributes with industry for practical } \\
\text { skills. }\end{array}$ \\
\hline 12. & $\begin{array}{l}\text { Jafar et } \\
\text { al. } \\
(2020)\end{array}$ & $\begin{array}{l}\text { TVET } \\
\text { human } \\
\text { resource }\end{array}$ & $\begin{array}{l}\text { 1.technical } \\
\text { 2.non-technical } \\
\text { 3.personal } \\
\text { 4.mental, and physical attributes } \\
\text { 5.motives } \\
\text { 6.self-concept. }\end{array}$ & $\begin{array}{l}\text { Non-technical competency is as } \\
\text { important as technical } \\
\text { competence. Personal attributes, } \\
\text { motive, and physical state are } \\
\text { important in the Industry } 4.0 \text { era } \\
\text { TVET teacher profession. }\end{array}$ \\
\hline
\end{tabular}

Abbreviations: EJP: effective job performance; MHRDP: Malaysian Human Resource Development Practitioners; ILP: Institut Latihan Perindustrian; MPST: Malaysian Public Skills Training Institutions; MOHR: Ministry of Human Resources; MOYS: Ministry of Youth and Sports; NOSS: National Occupational Skills Standard

\subsection{Imbalance of Technical and Non-Technical Competency}

Competent professional TVET educators are urged to have a balance of technical and non-technical competency to remain relevant (Jafar et al., 2020; Abdullah et al., 2019). Jafar et al. (2020) highlighted the importance of professional competencies constructs, to increase educator's performance, specifically during the industrial revolution 4.0 era. Not just that, personal attributes, motive, physical and mental endurance of the TVET educators should also be combined. The technical competency that was important comprises instructional design in planning, delivery, evaluation, classroom management, inspiring and facilitating student, student's career development, technology application as well as a deep understanding of subject matter play an important aspect to TVET education (Jafar et al., 2020).

While, non-technical competencies or generic, or soft skills should always be strengthened and balanced in line with essential skills and professionalism (Jafar et al., 2020). This is even more important during technological advancement, the provision of new sets of skills for lifelong learning has become the essential skill for TVET educator's career development (Abdullah et al., 2019). The rapid shift in the education paradigm which just happened today during the pandemic has demanded the TVET educators to improve their creativity, innovation, and critical thinking in the learning process and teaching strategies In term of imbalance competency between technical and non-technical professionalism, TVET educator should demonstrate readiness to practice, apply, and demonstrate the pertinent mastery, knowledge, skills, and attitudes as required by their duties and responsibilities. This professional competency surely reflects individual job attitudes and technical performance at work (Abdullah et al., 2019).

\subsection{Lack of Practical Skills Training and Work Experience}

The lack of skills training and work experience among TVET educators have been argued previously in Ismail et al. (2017) article. TVET educators are highly recommended to get thorough training in the industry and in training institutes that offer particular skills. According to Hamisu et al. (2017), the majority of Malaysian TVET educators were lack training and work experience, while among TVET fresh graduates who become educators have been identified with a lack of competency in the teaching profession (Ali, 2015). The TVET graduates, and TVET instructors, seem to lack technical and practical expertise. For instance, lack of understanding in the practical work process (Ali, 2015). They are more possibly just explain the process without demonstration. Abdul Suki et al. (2018) related this limitation among the junior TVET educator with a lack of self-confidence and practical skill in operating the machine. Senior educators and instructors certainly have higher skills and self-confidence in practical teaching (Abdul Suki et al., 2018). As for that, students' understanding could be increased during technical class. But after all, working experiences are not only a factor that influences the quality of the instructor. Interestingly, Abdul Suki et al.. (2018) found that the more experienced educators, the less likely they will receive cooperation as compared to educators who had recently worked. Even during the teaching process, the educator's leadership has been ignored. It makes the educators frail in supervising their students 
or trainees (Abdul Suki et al., 2018). Therefore, the existence of TVET educators and instructors that are cheerful, positive, and not "burnt-out", can reduce the trainee's and students' burdens during their teaching process.

\subsection{Issue of Greening TVET}

Greening TVET with green skills and sustainable economic growth are very important aspects to be fulfilled as a TVET educator in today's IR 4.0 era (Ismail et al., 2018). This green skill is important for TVET educators to accomplish the need of society and future nation capitals (Arifin \& Rasdi, 2017). Hamid et al. (2019) in a recent study have encouraged generic green skills in teaching and learning for upcoming manpower employability, especially for the green job labor market. To be a competent TVET educator, high awareness and practice of generic green skills should always be implemented as such the practice of e-learning, digital technology, electricity-saving, smartphone usage, and application of ICT in teaching material. The green concept which is a part of generic skill should be taught, learned, and nurtured towards the students too. As for that, TVET educators should understand and apply the generic green skills into green practices for conserving, preserving, and maintaining a quality environment. The greening TVET is a skill that combines harmoniously elements of knowledge, technical and non-technical skills as well as attitudes towards sustainable human resources. Thus, a combination of green education and training is important for TVET educators to cultivate a future workforce with the knowledge of ecologically friendly and sustainable technologies (Hamid et al., 2019).

\subsection{Lack of Self-Concept and Confidence in Improving Performance}

This part discusses TVET educator that lack in self-concept, self-development, self-control, and self-confidence in improving their job performance. Jafar et al. (2020) characterize the concept with a desire to build one's own life and as one of the ways to develop a TVET educator's profession. Through teaching experience, TVET educators should be more detailed and have a clear motive so that their desire for professional self-development can be more successful (Jafar et al., 2020). According to Ismail et al. (2018), the limitation in promotion for educators and proper guidelines for promoting educators is another issue that should be seen. Promotion must be based on merit and merit be based on quality, and quality is based on core competencies as well as the self-confidence of the educators.

Other than that, one of the aspects to be improved as emphasized by many authors is regarding English language confidences among TVET educators (Ismail et al., 2016; Ismail et al., 2017). In TVET education, most technical references are in English. Abdul Suki et al. (2018) has suggested more courses, presentation, programs, and research activities that could enhance the level of esteem, awareness, and attitude of TVET instructors to teach in English. Furthermore, improvement in English proficiency may also increase the TVET educator's self-confidence especially when need to handle the learning problems of weak students (Jafar et al., 2020).

\subsection{Lack of Pedagogical Approach for Social and Humanity Competency}

The absence and lack of social and humanity values among TVET educators have been highlighted by scholars Jaafar et al. (2020), Ismail et al. (2016), and Abdul Suki (2018). Although today's era is focusing on technology, TVET educators should have religiousness, honesty, politeness, reverence toward others, empathy, and tolerance (Jafar et al.,2020). The open-minded characteristic of TVET educators who are ready to face challenges and risks may help in preparing students without losing humanity, personality, and cultural value. Thus, educators should have outstanding personal characteristics to act as role models and provide quality education for the students (Jafar et al.,2020; Ismai et al., 2019). Ismail et al. (2016) have emphasized the importance of pedagogical approaches for social competency among TVET educators. The TVET teaching competencies emphasized were originated from The German System Model. This model was an integration set of technical, learning, methodological, and social competency, with aims for better job performance in various TVET teaching backgrounds. Therefore, it is crucial to draft a procedure for certifying the TVET educators as stated in the standard and requirements like in Vocational Training Operation (VTO) certification offered by the Department of Skill Development (DSD).

\section{Conclusion}

Despite the limited number of competency studies conducted among the various background of TVET educators in Malaysia, there are five emerging and current matters have been highlighted by most of the authors. These five matters about competence apply to all TVET educators across ages in Malaysia. Thus, the review concludes by suggesting educators progressively increase their knowledge and skills through theoretical and practical training and real experiences acquired from home and abroad. This will enhance their competencies in line with the national and international core standards, that aim to produce skilled, knowledgeable, and high-quality workforces in various TVET industries.

\section{Acknowledgment}

The authors would like to thank the Research Management Center of Universiti Teknologi Malaysia (UTM) and Ministry of Education Malaysia for FRGS Fund R.J130000.7853.5F118 who funded this study. 


\section{References}

Ali, M. (2015). Developing the knowledge-based human resources that support the implementation of the national dual training system (NDTS): Evaluation of TVET teacher's competency at Mara training institutions. Universiti Tun Hussein Onn Malaysia: Ph.D. Thesis

Abdul Suki, N., Yunus, F. A. N., Rahim, M. B., Masran, S. H., Marian, M. F., \& Abd Baser, J. (2018). Competency Of TVET Instructor Toward Technical Lesson In Institut Latihan Perindustrian (ILP). Online Journal for TVET Practitioners, 3(1)

Abdullah, Z., Hoque, K. E., Ramlan, N. H., \& Shafee, S. (2019). Designing the Structural Model of TVET Lecturers' Professionalism and Generic Skills Based on an Empirical Study in Malaysia. SAGE Open, 9(3), https://doi.org/10.1177/2158244019861456

Affero I., Razali H., Alias M., Norhasyimah H., Irwan M.I. \& Tamil S.S. (2016). Implementation of Vocational Training into TVET's Teacher Program for National Core Standard. IEEE 8th International Conference on Engineering Education (ICEED)

Aliakbari, M. \& Darabi, R. (2013). On the Relationship between Efficacy of Classroom Management, Transformational Leadership Style, and Teachers' Personality. Procedia - Social and Behavioral Sciences 23: 1716-172

Arifin, M. A., \& Rasdi, R. M. (2017). The Competent Vocational College Teacher: A Proposed Model for Effective Job Performance. International Journal of Academic Research in Business and Social Sciences, 7(2), 9

Arifin, M. A., Rasdi, R. M., Anuar, M. A. M., \& Omar, M. K. (2017). Addressing Competency Gaps for Vocational Instructor through Competency Modelling. International Journal of Academic Research in Business and Social Sciences, 7(4), Pages 1201-1216. https://doi.org/10.6007/IJARBSS/v7-i4/2970

Arifin, M. A., Rasdi, R. M., Anuar, M. A. M., \& Omar, M. K. (2018). Competencies of Vocational Teacher: A Personnel Measurement Framework. International Journal of Academic Research in Business and Social Sciences, 7(14), Pages 147-164. https://doi.org/10.6007/IJARBSS/v7-i14/3659

Boyatzis, R. (1982). The Competent Manager: A Model for Effective Performance, John Wiley \& Sons, New York

Diep, P.C. \& Hartmann, M. (2016). Green Skills in Vocational Teacher Education - a model of pedagogical competence for a world of sustainable development. www.tvet-online.Asia, issue 6

Guthrie, H. (2010). Professional development in vocational education and training workforce. National Centre for Vocational Education Research, Australia

Hamid, M. Z. A., Hassan, Z., Nordin, M. S., Kamin, Y., Atan, N. A., \& Suhairom, N. (2019). Generic Green Skills in Teaching and Learning: Meaning and Implementation. Universal Journal of Educational Research, 7(12A), $121-126$. https://doi.org/10.13189/ujer.2019.071915

Hamisu, M. A., Salleh, K. M., Sern, L. C., \& Abubakar, A. (2017). Proposed Competency Framework For Malaysian Technical And Vocational Education And Training (TVET) Teachers. European Journal of Education Studies, 9(3), Pages 286-299

ILO. (2010). Teachers and trainers for the future - Technical and vocational education and training in a changing world, International Labour Organization

Ismail, A. Hassan, R., Abu Bakar, A., Hussin, H., Mat Hanafiah, M. A.\& Asary, L. H. (2018). The Development of Tvet Educator Competencies for Quality Educator. Journal of Technical Education and Training (JTET)

Ismail, A., Hassan, R., and Rosli, D. I. (2017). The Skill and Competency of Technical and Vocational Education and Training (TVET) Personnel for the Development and Implementation of a National Teacher Standard in TVET in Malaysia. Pertanika J. Soc. Sci. \& Hum. 25 (S): 109-120 
Ismail, K., Nopiah, Z. M., Rasul, M. S., \& Leong, P. C. (2017). Malaysian teachers' competency in technical vocational education and training: A review. In A. G. Abdullah, T. Aryanti, A. Setiawan, \& M. B. Alias (Eds.), Regionalization and Harmonization in TVET (1st ed., pp. 59-64). Routledge. https://doi.org/10.1201/9781315166568-12

Ismail K., Zulkifli M. N., Mohamad S. R. \& Pang Chau Leong. (2019). Development of Competency Items For Vocational Teachers Using Rasch Model Analysis. Journal of Engineering Science and Technology Special Issue on ICEES2018, June (2019) 51 - 58. School of Engineering, Taylor's University

Jafar, D. S. A., Saud, M. S., Hamid, M. Z. A., Suhairom, N., Hisham, M. H. M., \& Zaid, Y. H. (2020). TVET Teacher Professional Competency Framework in Industry 4.0 Era. Universal Journal of Educational Research, 8(5), $1969-1979$. https://doi.org/10.13189/ujer.2020.080534

Kleickmann, T., Richter, D., Kunter, M., Elsner, J., Besser, M., Krauss, S. \& Baumert, J. (2012). Teachers’ Content Knowledge and Pedagogical Content Knowledge: The Role of Structural Differences in Teacher Education. Journal of Teacher Education 64(1): 90-106

Mirzagitova, A.L. \& Akhmetov, L.G. (2015). Self-development of pedagogical competence of the future teacher. International Education Studies 8(3): 114-12

Moher, D., A. Liberati, J. Tetzlaff, D. G. Altman, D. Altman, G. Antes, D. Atkins, V. Barbour, N. Barrowman, J. A. Berlin, J. Clark, M. Clarke, D. Cook, R. D’Amico, J. J. Deeks, P. J. Devereaux, K. Dickersin, M. Egger, E. Ernst, P. C. Gøtzsche, J. Grimshaw, G. Guyatt, J. Higgins, J. P. A. Ioannidis, J. Kleijnen, T. Lang, N. Magrini, D. McNamee, L. Moja, C. Mulrow, M. Napoli, A. Oxman, B. Pham, D. Rennie, M. Sampson, K. F. Schulz, P. G. Shekelle, D. Tovey, and P. Tugwell. (2009). Preferred reporting items for systematic reviews and meta-analyses: the PRISMA statement. PLoS Med. 6:e1000097

Othman, A., Abdullah, N.H., Sulaiman, M., Shamsuddin, A. (2011). The Emerging Roles of Coaches in the Malaysian Dual Training System. International Education Studies 4(1): 154-160. Retrieved from https://publisher.uthm.edu.my/ojs/index.php/oj-tp/article/view/4836

Spencer, L. \& Spencer, S. (1993). Competence at Work: Models for Superior Performance. John Wiley \& Sons, New York

UNESCO Global Monitoring Report. (2014). Global Monitoring Report 2013/4: Teaching and Learning: Achieving quality for all. United Nations Educational Scientific and Cultural Organization

Wesselink, R., Dekker-Groen, A.M., Biemens, H.J.A. \& Mulder, M. (2010). Using an instrument to analyze competencebased study programs: experiences of teachers in Dutch vocational education and training. Journal of Curriculum Studies 42(6): 813-829 